\title{
UM CORONEL EM REVISTA \\ VILELA, Márcio Ananias Ferreira. A Trajetória \\ Politica de Francisco Heráclito do Rego
}

Recife: Editora Universitária da UFPE, 2014

Severino Vicente da Silva*

\section{A Colonel in review}

VILELA, Márcio Ananias Ferreira. A Trajetória Política de Francisco Heráclito do Rego. Recife: Editora Universitária da UFPE, 2014.

PALAVRAS CHAVE : Coronelismo; Limoeiro, Pernambuco; Partidos Políticos KEYWORDS : Coronelismo, Limoeiro, Pernambuco; Political Parties

Fruto da pesquisa para alcançar o grau de mestre em História pela Universidade Federal de Pernambuco, orientado pelo professor Dr. Antônio Torres Montenegro, Márcio Vilela nos apresenta um interessante trabalho, em escrita leve, sem o pedantismo que quase caracteriza as produções acadêmicas, a respeito de um dos últimos coronéis que atuaram e marcaram, durante bastante tempo, a vida social e política do Brasil e, com maior longevidade no Nordeste. O livro nos entregue dividido em seis partes, sendo as duas últimas dedicadas à bibliografia e aos anexos. A primeira parte, formada por dois capítulos encarregados de nos atualizar sobre as bases teóricas utilizadas na análise dos documentos e depoimentos recolhidos, mas, principalmente para nos oferecer uma recensão crítica dos estudos clássicos sobre o coronelismo no Brasil como os de Victor Nunes Leal ${ }^{1}$, Raymundo Faoro ${ }^{2}$, Maria Isaura de Queiroz ${ }^{3}$, mas detendo-se com maior cuidado nos casos de Pernambuco, Sergipe e Ceará, estudos por Marcos Venicios Vilaça/ Roberto Cavalcanti ${ }^{4}$, Iberê Dantas ${ }^{5}$, Maria Auxiliadora Lamenhe $^{6}$, além de um estudo mais acurado sobre o Mandonismo, seguindo as trilhas abertas por José Murilo Carvalho. ${ }^{7}$

A segunda parte, composta de cinco capítulos dedica-se a desvelar o Mecanismo de construção de um líder político. Mas, quando lemos o escrito, vemos que nosso autor nos leva também ao processo de manutenção dessa liderança, que veio a esbarrar no processo modernizador da modernidade da qual ela é parte.

*Doutor em História pela Universidade Federal de Pernambuco. Atualmente é professor associado do Departamento de História da Universidade Federal de Pernambuco. Contato: Av. da Arquitetura, s/n CFCH-11 ${ }^{\circ}$ Andar, CDU - CEP: 50740-550, Recife-PE, Brasil. E-mail: severino.vicente@gmail.com. 
Francisco Heráclito do Rego, referendado popularmente como Chico Heráclito, foi uma força política que se firmou após os anos de 1930 na região Agreste de Pernambuco, na senda do Partido Social Democrático, fundado após a ditadura do Estado Novo, encabeçada por Getúlio Vargas e, em Pernambuco, capitaneada pelo sertanejo Agamenon Magalhães. Analfabeto, Francisco Heráclito soube usar as nuances da literatura, manejando a mão de Antônio Vilaça, pai de Marcos Venicios Vilaça ${ }^{8}$, para comunicar-se com os alfabetizados e os analfabetos que viviam nas cidades e povoados que cresceram sob a sua proteção e cuidado.

Cinco capítulos formam a segunda parte deste estudo e eles estão voltados para nos auxiliar a entender como se forjou e se construiu uma liderança política, ora apelando para o encontro direto e pessoal com os agentes social, ora usando indisfarçadamente a produção literária, nos jornais, em boletins, em cordéis lidos e proclamados nas feiras livres da região e nas praças do Recife, onde também tinha eleitores que voltavam a cada eleição para sufragar aqueles indicados pelo Senhor das Varjadas. Márcio Vilela nos apresenta aspectos interessantes como a utilização do patriarca, João Heráclito do Rego, morto em 1934, que evitou uma participação politica ostensiva, cabendo essa atividade ao seu filho, que teria sido ungido, ainda no seio materno, (p 109ss) para liderar a família e a região. Aqui uma observação. Márcio Vilela, que nos recorda que a escolha do nome, Francisco, homenagem ao Santo de Assis, celebrado um dia antes do nascimento, a cinco de outubro - que há uma indicação de que ele nasceu para servir aos pobres.

Mas ainda há outro estranhamento, de que nos dias seguintes ao nascimento de Francisco Heráclito, seu pai já está a postos, no roçado e não obedecendo ao ritual de dedicar os dias seguintes ao nascimento do herdeiro em comemorações, o que, na região denomina-se 'cachimbo'. ...quebrava uma tradição muito comum e de algumas regiões do Brasil serem os primeiros cinco dias após o nascimento de uma criança reservado às comemorações do ao acontecido. Na nota 32, nosso autor lembra que o cachimbo é uma bebida composta de cachaça, água e mel. Lembra ainda que esta bebida é apreciada após o nascimento. Aqui, creio que uma visita à tradição europeia que enaltece São Francisco de Assis e o esforço para colocar esse coronel na sua tradição, uma tradição de civilização, educação e própria da formação tradicional e culturalmente 
dominante, há outra preocupação: a de afastar o nascituro, futuro líder político da organização e modernização da cidade do Limoeiro das tradições indígenas.

Sabemos da prática da couvade entre nossos antepassados indígenas e, nela o repouso pós-parto era próprio para o pai da criança que, dessa forma, anunciava socialmente a paternidade social da criança. A bebida com mel é ofertada, ainda hoje nos cultos da Jurema Sagrada, religião de cunho e raízes profundamente brasileiras, mas que à época era praticada por poucos, e nas matas, distante dos olhares dos civilizados. Esses acontecimentos - o pai trabalhando no dia seguinte ao nascimento do filho e não utilização do cachimbo, é o esforço de afastar aquela família dos "caboclos do mato", dos índios que naquele período eram conceituados bem negativamente. Assim São muitos os cuidados no processo de criação de um mito ou liderança.

A terceira parte do livro nos remete às práticas deste e de outros coronéis que atuaram no período da chamada Democracia Liberal, entre os anos de 1945 e 1964. São cinco capítulos, dois deles dedicados a analisar a situação econômica, social e política de Limoeiro e o lugar que o líder ocupa naquele momento da vida local e nacional e dois capítulos dedicados a compreender como agia este líder para manter seu prestígio e respeito social, as suas práticas diárias, o seu comportamento no período eleitoral e sua reação àqueles que não seguiram as suas ordenações e ordenamentos. E essa era uma situação nova, a prática democrática começava a por em dívida o poder de mando. É um período de ruptura com outros agentes da cúpula do PSD, e por isso é o início de um novo tempo, que não está na preocupação de Márcio Vilela, mas que ele tangencia, sem chamar a atenção necessária, que o processo de formação de novos coronéis, novos senhores dos votos que assimilam algumas práticas e introduzirão novas.

Nas eleições de 1954, pensando em sentar-se na cadeira presidencial, Etelvino Lins faz emergir a candidatura do General Cordeiro de Farias, em uma aliança que envolve o PSD, o PL, PRT, PSP e dissidentes udenistas. Dizia Etelvino que era uma chapa para unir Pernambuco, como lembrado por Cordeiro de Farias, em depoimento ao CPDOC, e provocou a divisão do PSD que apoio Neto Campelo, com outros partidos, entre eles o PST. Neste partido estava Miguel Arraes de Alencar que, mais tarde veio a ser eleito governador de Pernambuco apoiado por essa dissidência do PSD, uma aliança com os coronéis. Embora não fosse esse o objetivo da dissertação de Marcio Vilela, teria sido interessante uma nota de pé de página no sentido de apontar como as relações políticas e pessoais orientam os caminhos dos homens na história. 


\section{Notas}

\footnotetext{
${ }^{1}$ LEAL, Victor Nunes. Coronelismo, Enxada e Voto: o município e o regime representativo no Brasil. Riod e Janeiro Nova Fronteira, 1997.

${ }^{2}$ FAORO, Raymundo. Os donos do Poder. São Paulo: Globo, 2001.

${ }^{3}$ QUEIROZ, Maria Isaura Pereira de. O Mandonismo local na vida política brasileira e outros ensaios. São Paulo: Alfa-Omega, 1976.

${ }^{4}$ VILAÇA, Marcos Venicios; ALBUQUERQUE, Roberto Cavalcanti de.

${ }^{5}$ DANTAS, Iberê. Coronelismo e dominação. Aracaju: Universidade Federal de Sergipe, PROEX/CECAC/ PROGRAMA EDITORAL,1987.

${ }^{6}$ LEMENHE, Maria Auxiliadora. Família Tradição e Poder: o (caso) dos coronéis. São Paulo, ANNALUBE/Edições, 1995. Coronel, coronéis: apogeu e declínio dos coronéis no Nordeste. Riod e Janeiro: Bertrand Brasil, 2003.

${ }^{7}$ CARVALHO, José Murilo de. Pontos e Bordados: escritos de história e política. Belo Horizonte: Editora da UFMG, 1998.

${ }^{8}$ O poeta é hoje membro da Academia Brasileira de Letras.
} 